\title{
THE AMOUNT AND COMPOSITION OF THE DRAINAGE THROUGH UNMANURED AND UNCROPPED LAND, BARNFIELD, ROTHAMSTED.
}

BY N. H. J. MILLER, PH.D., F.I.C.

\section{(Lawes Agricultural Trust.)}

DURING the last sixty years numerous percolation and evaporation experiments have been made in this country and elsewhere. The method employed has been that originally used by Dalton, which has the advantage that the chenical and physical properties of the soil may, if desired, be thoronghly investigated. In addition to these experiments in which the evaporation from the soil, or from the soil with vegetation, is estimated by deducting the amount of drainage from the rainfall of the same period, numerous determinations of soil moisture have been made in the United States, from which evaporation may be directly determined. The difference between the estimated evaporation and the rainfall gives of course the amount of percolation.

Recently, King (9) has determined the evaporation from soils supplied from below with a constant water-supply, by means of large cylinders 4 feet in diameter and 2 feet deep. He has also determined the amounts of water evaporated by plants growing in similar cylinders 4 feet deep.

The Rothamsted gauges differ from those of Dalton in containing undisturbed soil. Soil which has been put into cylinders and subjected to the action of rain, will no doubt, as time goes on, acquire a more and more natural condition of consolidation, but we cannot know when this desirable condition is completed and can only take it for granted after a considerable time. The Barnfield gauges are free from this disadvantage, and as a means of measuring drainage, which is what they were mainly intended for, leave very little to be desired, As regards, however, the 
relation of the constituents of the drainage to those of the soil, our knowledge must always be somewhat imperfect, since it is obviously impossible to obtain exact estimates of what the soil originally contained.

The results relating to the amounts of drainage and of nitrogen as nitrates in the drainage have been published each year from 1882 to 1901 in the Rothamsted "Memoranda" and recently in "Field Plans." Collected results relating to percolation only were published by Gilbert in 1891 (5), and more recently by R. H. Scott (7); whilst the more complete paper of Lawes, Gilbert, and Warington (3) deals with the whole subject, and contains the chemical results up to April, 1881.

On the present occasion it is proposed to bring together the whole of the results from the commencement. It will, however, be desirable first of all to give a short account of the gauges, as the earlier papers on the subject are not always accessible.

The three Rothamsted drain-gauges, having each an area of $1 / 1000$ th of an acre, were constructed in the summer of 1870 by undermining the soil at the desired depths (20,40, and 60 inches respectively), and inserting perforated iron plates beneath the soil to support it as the undermining proceeded. When this was completed, trenches were made on the other three sides of the blocks of soil, and these were then isolated by means of $4 \frac{1}{2}$ inch brick walls. The external soil was then returned.

In 1874, leakage from the outside being suspected, the outsides of the walls of the gauges were exposed and covered with cement, and their thickness increased by another $4 \frac{1}{2}$ inches of bricks. In 1879, one of the walls of the 20 -inch gauge received an extra coating of cement on its outer surface. Since then no structural alteration has been made in any of the gauges.

The drainage passing through the perforated iron plates which support the soil, falls into zinc funnels and flows from these into the measuring cylinders. During the first three years, however, the drainage was collected in carboys and weighed.

The Rothamsted soil' may be described as a rather heavy loam, with a reddish-yellow subsoil over chalk. Both the surface and the subsoil contain very large, and also very variable, amounts of flints.

As regards the cropping and manuring of the portion of the field on which the gauges were built it should be stated that before 1870 it

1 H. B. Woodward, 'Report on the Soils and Subsoils of the Rothamsted Estate,' Summary of Progress of the Geological Survey for 1903. 
had been under ordinary arable cultivation, artificial manures generally with guano, being employed. In 1870 the land was fallow.

In June, 1870, samples of soil were taken near the position now occupied by the gauges, both on the bare ground and on the barley land beyond. In the following table are given the results of nitrogen determinations made at the time in the samples from the bare ground, together with more recent determinations of calcium carbonate and chlorine. The amounts per acre are calculated from average weights of Rothamsted soils generally : for the first 9 inches, 2,400,000 lbs., for the second 9 inches $2,650,000$, for the third and fourth 9 inches 2,700,000, and for the lower depths $2,800,000$ lbs. per acre.

\section{TABLE I.}

Amounts of Nitrogen, Chlorine, and Calcium Carbonate in Soil Samples taken from the Bare Ground near the Gauges in 1870.

\begin{tabular}{|c|c|c|c|c|c|c|c|}
\hline & & \multicolumn{3}{|c|}{ In fine, dry soil } & \multicolumn{3}{|c|}{ Per Acre } \\
\hline & & Nitrogen & Chlorine & $\begin{array}{l}\text { Calcium } \\
\text { carbonate }\end{array}$ & Nitrogen & Chlorine & $\begin{array}{l}\text { Cslcium } \\
\text { carbonate }\end{array}$ \\
\hline $\begin{array}{l}\text { First } \\
\text { Second } \\
\text { Third } \\
\text { Fourth } \\
\text { Fifth } \\
\text { Sixth }\end{array}$ & $\begin{array}{cc}9 & \text { inches } \\
& \\
" & \ldots \\
" & \ldots \\
" & \ldots \\
" & \ldots \\
" & \ldots\end{array}$ & $\begin{array}{c}\text { per cent. } \\
0.146 \\
0.078 \\
0.076 \\
0.076 \\
0.061 \\
0.057\end{array}$ & $\begin{array}{c}\text { per cent. } \\
0.00242 \\
0.00195 \\
0.00190 \\
0.00192 \\
0.00199 \\
0.00158\end{array}$ & $\begin{array}{c}\text { per cent. } \\
3.06 \\
0.32 \\
0.12 \\
0.15 \\
0.11 \\
0.18\end{array}$ & $\begin{array}{c}\text { lbs. } \\
3,504 \\
2,067 \\
2,052 \\
2,052 \\
1,708 \\
1,596\end{array}$ & $\begin{array}{l}\text { lbs. } \\
58 \cdot 1 \\
51 \cdot 7 \\
51 \cdot 3 \\
51 \cdot 8 \\
55 \cdot 7 \\
44 \cdot 2\end{array}$ & $\begin{array}{r}\text { lbs. } \\
73,440 \\
8,480 \\
\mathbf{3 , 2 4 0} \\
\mathbf{4 , 0 5 0} \\
\mathbf{3 , 0 8 0} \\
\mathbf{5 , 0 4 0}\end{array}$ \\
\hline
\end{tabular}

According to these estimates the initial amounts of the three constituents in the soil of the $20-, 40-$, and 60 -inch gauges will be in lbs. per acre as follows:

$\begin{array}{crrrrr} & & & \text { Nitrogen } & \text { Chlorine } & \text { Calcium carbonate } \\ \text { Soil } 20 \text { inches deep } \ldots \ldots \ldots . & 6,027 & 121 & 82,640 \\ \text { " } 40 & & \ldots \ldots \ldots . & 10,434 & 238 & 90,579 \\ " 60 & \# & \ldots \ldots \ldots . & 14,043 & 342 & 100,690\end{array}$

\section{Percolation and Evaporation.}

The average yearly amounts of water percolating through 20,40, and 60 inches of soil are very similar and amount to about 14 inches, or approximately half the rainfall. The results obtained with the 
20- and 60-inch gauges are indeed practically identical' ${ }^{1}$; whilst the 40 -inch gauge yields on the average nearly 1 inch more drainage than the others.

TABLE II.

Yearly Amounts of Drainuge through 20, 40, and 60 inches of Bare Soil.

\begin{tabular}{|c|c|c|c|c|c|c|c|c|c|c|}
\hline \multirow{2}{*}{$\begin{array}{l}\text { Sept. } 1 \\
\text { to } \\
\text { Aug. } 31\end{array}$} & \multirow{2}{*}{$\begin{array}{c}\text { Rain- } \\
\text { fall }\end{array}$} & \multicolumn{3}{|c|}{ Drainage } & \multicolumn{3}{|c|}{ Drainage $\%$ of Rainfall } & \multicolumn{3}{|c|}{ Evaporation } \\
\hline & & $\begin{array}{c}20 \text {-inch } \\
\text { gauge }\end{array}$ & $\begin{array}{l}\text { 40-inch } \\
\text { gauge }\end{array}$ & $\begin{array}{c}60 \text {-inch } \\
\text { gauge }\end{array}$ & $\begin{array}{c}20 \text {-inch } \\
\text { gauge }\end{array}$ & $\begin{array}{c}\text { 40-inch } \\
\text { gauge }\end{array}$ & $\begin{array}{l}\text { 60-inch } \\
\text { gauge }\end{array}$ & $\begin{array}{c}20 \text {-iuch } \\
\text { gruge }\end{array}$ & $\begin{array}{c}40 \text {-inch } \\
\text { gauge }\end{array}$ & $\begin{array}{c}60 \text {-inch } \\
\text { gauge }\end{array}$ \\
\hline & inches & inches & inches & inches & & & & inches & inches & inches \\
\hline $1870-1$ & $27 \cdot 55$ & $9 \cdot 64$ & $9 \cdot 42$ & $5 \cdot 81$ & $35 \cdot 0$ & $34 \cdot 2$ & $21 \cdot 1$ & $17 \cdot 91$ & $18 \cdot 13$ & $21 \cdot 74$ \\
\hline $1-2$ & $29 \cdot 02$ & $9 \cdot 69$ & $9 \cdot 39$ & $8 \cdot 24$ & $33 \cdot 4$ & $32 \cdot 4$ & $28 \cdot 4$ & $19 \cdot 33$ & $19 \cdot 63$ & $20 \cdot 78$ \\
\hline $2-3$ & 30.66 & $14 \cdot 35$ & $13 \cdot 67$ & $12 \cdot 03$ & $46 \cdot 8$ & $44 \cdot 6$ & $39 \cdot 2$ & $16 \cdot 31$ & $16 \cdot 99$ & $18 \cdot 63$ \\
\hline $3-4$ & $21 \cdot 69$ & $5 \cdot 74$ & $5 \cdot 40$ & $3 \cdot 94$ & $26 \cdot 5$ & $24 \cdot 9$ & $18 \cdot 2$ & $15 \cdot 95$ & $16 \cdot 29$ & $17 \cdot 75$ \\
\hline $4-5$ & $31 \cdot 61$ & $12 \cdot 25$ & $12 \cdot 72$ & $10 \cdot 30$ & $38 \cdot 7$ & $40 \cdot 2$ & $32 \cdot 6$ & $19 \cdot 36$ & 18.89 & $21 \cdot 31$ \\
\hline $5-6$ & $31 \cdot 98$ & $14 \cdot 75$ & $16 \cdot 87$ & $15 \cdot 46$ & $46 \cdot 1$ & $52 \cdot 7$ & $48 \cdot 3$ & $17 \cdot 23$ & $15 \cdot 11$ & 16.52 \\
\hline $6-7$ & $39 \cdot 28$ & $19 \cdot 63$ & $22 \cdot 07$ & $20 \cdot 20$ & $50 \cdot 0$ & $56 \cdot 2$ & $51 \cdot 4$ & $19 \cdot 65$ & $17 \cdot 21$ & $19 \cdot 08$ \\
\hline $7-8$ & $32 \cdot 65$ & $14 \cdot 72$ & $16 \cdot 44$ & $14 \cdot 84$ & $45 \cdot 1$ & $50 \cdot 4$ & $45 \cdot 5$ & $17 \cdot 93$ & $16 \cdot 21$ & $17 \cdot 81$ \\
\hline $8-9$ & $41 \cdot 05$ & $24 \cdot 44$ & 26.03 & $24 \cdot 38$ & $59 \cdot 5$ & $63 \cdot 4$ & $59 \cdot 4$ & $16 \cdot 61$ & 15.02 & $16 \cdot 67$ \\
\hline $9-80$ & $21 \cdot 36$ & 6.89 & $7 \cdot 39$ & 6.50 & $32 \cdot 3$ & $34 \cdot 6$ & $30 \cdot 4$ & $14 \cdot 47$ & $13 \cdot 97$ & $14 \cdot 86$ \\
\hline $1880-1$ & $36 \cdot 77$ & $22 \cdot 38$ & $22 \cdot 84$ & $21 \cdot 26$ & $60 \cdot 9$ & $62 \cdot 1$ & $57 \cdot 8$ & $14 \cdot 39$ & $13 \cdot 93$ & $15 \cdot 51$ \\
\hline 1-2 & $32 \cdot 31$ & $15 \cdot 81$ & $16 \cdot 08$ & $14 \cdot 32$ & $48 \cdot 9$ & $49 \cdot 8$ & $44 \cdot 3$ & $16 \cdot 50$ & $16 \cdot 23$ & $17 \cdot 99$ \\
\hline $2-3$ & $34 \cdot 71$ & $20 \cdot 82$ & $21 \cdot 72$ & $19 \cdot 72$ & $60 \cdot 0$ & $62 \cdot 6$ & $56 \cdot 8$ & $13 \cdot 89$ & $12 \cdot 99$ & 14.99 \\
\hline $3-4$ & $25 \cdot 77$ & $11 \cdot 86$ & $12 \cdot 00$ & $11 \cdot 21$ & $46^{\circ} 0$ & $46 \cdot 6$ & $43 \cdot 5$ & $13 \cdot 91$ & $13 \cdot 77$ & 14.56 \\
\hline $4-5$ & $26 \cdot 78$ & $14 \cdot 82$ & $15 \cdot 14$ & $13 \cdot 98$ & $55 \cdot 3$ & 56.5 & $52 \cdot 2$ & $11 \cdot 96$ & $11 \cdot 64$ & $12 \cdot 80$ \\
\hline $5-6$ & 31.02 & $17 \cdot 37$ & $18 \cdot 41$ & 16.57 & $56 \cdot 0$ & $59 \cdot 3$ & $53 \cdot 4$ & $13 \cdot 65$ & $12 \cdot 61$ & $14 \cdot 45$ \\
\hline $6-7$ & $23 \cdot 61$ & $10 \cdot 64$ & $12 \cdot 58$ & $11 \cdot 72$ & $45 \cdot 1$ & $53 \cdot 3$ & $49 \cdot 6$ & $12 \cdot 97$ & $11 \cdot 03$ & $11 \cdot 89$ \\
\hline $7-8$ & 30.50 & $13 \cdot 96$ & $15 \cdot 58$ & $14 \cdot 67$ & $45 \cdot 7$ & $51 \cdot 1$ & $48 \cdot 1$ & $16 \cdot 54$ & 14.92 & $15 \cdot 83$ \\
\hline $8-9$ & 30.09 & $14 \cdot 64$ & $15 \cdot 82$ & $14 \cdot 33$ & $48 \cdot 7$ & $52 \cdot \overline{6}$ & $47 \cdot 6$ & $15 \cdot 45$ & $14 \cdot 27$ & $15 \cdot 76$ \\
\hline 9-90 & $27 \cdot 43$ & $13 \cdot 16$ & $13 \cdot 60$ & $12 \cdot 74$ & $48^{\circ} 0$ & $49 \cdot 6$ & $46 \cdot 4$ & $14 \cdot 27$ & $13 \cdot 83$ & $14 \cdot 69$ \\
\hline $1890-1$ & $23 \cdot 41$ & $9 \cdot 95$ & $9 \cdot 70$ & $9 \cdot 73$ & $42 \cdot 5$ & $41 \cdot 4$ & $41 \cdot 6$ & 13.46 & $13 \cdot 71$ & 13.68 \\
\hline $1-2$ & $29 \cdot 68$ & $16 \cdot 50$ & $17 \cdot 43$ & $16 \cdot 47$ & $55 \cdot 6$ & $58 \cdot 7$ & $55 \cdot 5$ & $13 \cdot 18$ & $12 \cdot 25$ & $13 \cdot 21$ \\
\hline $2-3$ & $24 \cdot 08$ & 11.58 & $12 \cdot 35$ & $12 \cdot 10$ & $48 \cdot 1$ & $51 \cdot 3$ & $50 \cdot 3$ & $12 \cdot 50$ & $11 \cdot 73$ & $11 \cdot 98$ \\
\hline $3-4$ & $29 \cdot 55$ & $13 \cdot 36$ & $14 \cdot 11$ & $14 \cdot 07$ & $45 \cdot 2$ & $47 \cdot 7$ & $47 \cdot 6$ & $16 \cdot 19$ & $15 \cdot 44$ & $15 \cdot 48$ \\
\hline $4-5$ & $28 \cdot 94$ & $15 \cdot 50$ & $16 \cdot 95$ & $16 \cdot 31$ & $53 \cdot 5$ & $58 \cdot 6$ & $56 \cdot 4$ & $13 \cdot 44$ & 11.99 & $12 \cdot 63$ \\
\hline $5-6$ & $24 \cdot 37$ & $9 \cdot 84$ & $10 \cdot 75$ & 10.35 & 40.4 & $44 \cdot 1$ & $42 \cdot 5$ & $14 \cdot 53$ & $13 \cdot 62$ & $14 \cdot 02$ \\
\hline $6-7$ & $37 \cdot 24$ & $21 \cdot 88$ & $23 \cdot 86$ & $\cdot 22 \cdot 80$ & $58 \cdot \overline{8}$ & $64 \cdot 1$ & $61 \cdot 2$ & $15 \cdot 36$ & $13 \cdot 38$ & $14 \cdot 44$ \\
\hline $7-8$ & $19 \cdot 51$ & $5 \cdot 95$ & 6.66 & $6 \cdot 47$ & $30 \cdot 5$ & $34 \cdot 1$ & $33 \cdot 2$ & $13 \cdot 56$ & $12 \cdot 85$ & $13 \cdot 04$ \\
\hline $8-9$ & $24 \cdot 70$ & $11 \cdot 99$ & $12 \cdot 48$ & $12 \cdot 48$ & $48 \cdot 6$ & 50.5 & 50.5 & $12 \cdot 71$ & $12 \cdot 22$ & $12 \cdot 22$ \\
\hline $9-1900$ & 31.02 & $16 \cdot 33$ & 16.93 & 17.02 & $52 \cdot 6$ & $54 \cdot 6$ & $54 \cdot 9$ & 14.69 & 14.09 & $14 \cdot 00$ \\
\hline $1900-1$ & $24 \cdot 30$ & 10.91 & $12 \cdot 35$ & 11.92 & $44 \cdot 9$ & $50 \cdot 8$ & $49 \cdot 1$ & $13 \cdot 39$ & 11.95 & $12 \cdot 38$ \\
\hline 1-2 & $23 \cdot 26$ & $8 \cdot 75$ & $9 \cdot 32$ & $9 \cdot 44$ & $37 \cdot 6$ & $40 \cdot 1$ & 40.6 & $14 \cdot 51$ & $13 \cdot 94$ & $13 \cdot 82$ \\
\hline $2-3$ & $31 \cdot 25$ & $16 \cdot 33$ & $17 \cdot 09$ & $17 \cdot 59$ & $52 \cdot 3$ & $54 \cdot 7$ & $56 \cdot 3$ & 14.92 & $14 \cdot 16$ & $13 \cdot 66$ \\
\hline $3-4$ & 31.50 & $17 \cdot 68$ & 17.92 & $18 \cdot 29$ & $56 \cdot 1$ & 56.9 & $58 \cdot 1$ & 13.82 & 13.58 & $13 \cdot 21$ \\
\hline $4-5$ & $25 \cdot 30$ & $10 \cdot 10$ & $10 \cdot 45$ & $10 \cdot 36$ & $39 \cdot 9$ & $41 \cdot 3$ & 40.9 & $15 \cdot 20$ & $14 \cdot 85$ & $14 \cdot 94$ \\
\hline
\end{tabular}

1 It may be mentioned that the summer of 1870 , at the end of which the ganges were made, was very dry and that the soil must have lost considerable amounts of water by evaporation from the exposed sides, the deeper the gauge the greater, of course, the loss. Evidence of this is furnished by the first year's percolatiou results, the 20 -inch gauge giving 9.64 and the 60 -inch gauge only 5.81 inches. When this first year is excluded, the averages (34 years) for the two gauges differ by only 0.08 inch. 
The yearly amounts of drainage show in each case (Table II) great variations, depending partly on the total rainfall and partly on the distribution of the rain during the year. Averages of several years arranged according to the magnitude of the rainfall show a regular increase in the amount of drainage (see Table III), but in individual years there may be low drainage with relatively bigh rainfall, and vice versa. In the year 1881-2, for instance, a year of high rainfall, following a year of still greater rainfall, the percentage of drainage through 60 inches of soil was slightly below the average, although as a rule a high rainfall is coincident with a relatively higher amount of drainage. In 1889-90, a year of average rainfall, also following one of high rainfall, the amount of drainage was low in all three gauges. The generally small differences between the yearly drainage through 20 and 60 inches of soil seem to have no connexion with the amount of the rainfall, and are difficult to account for. During the first twenty-two years of the experiments the 20 -inch gauge generally gave more drainage than the 60 -inch gauge; during the last thirteen years the reverse has occurred without exception.

TABLE III.

Average Amounts of Drainage and Evaporation in yeurs of Low, Average, and High Rainfall (60-inch Gauge), 1870-1 to 1904-5.

\begin{tabular}{|r|c|c|c|c|}
\hline & Rainfall & \multicolumn{2}{|c|}{ Drainage } & \multirow{2}{*}{ Evaporation } \\
\cline { 2 - 3 } & inches & inches & per cent. & inches \\
Rainfall below 26 inches ...... & $23 \cdot 45$ & $9 \cdot 69$ & $41 \cdot 3$ & $13 \cdot 76$ \\
,$" \quad 26-30$ inches........ & $28 \cdot 42$ & $12 \cdot 52$ & $44 \cdot 1$ & $15 \cdot 90$ \\
above 30 inches ....... & $33 \cdot 35$ & $\mathbf{1 7} \cdot 11$ & $51 \cdot 3$ & $16 \cdot 24$ \\
\hline
\end{tabular}

The differences between the amounts of rain and drainage-due partly to evaporation and partly to retention by the soil, when we are dealing with individual years or months, and to evaporation alone in the case of averages of several years-show less variation from year to year than either rainfall or drainage. The evaporation from the 20 -inch gauge has varied from 11.96 to 19.33 (average 15.13 inches), and from the 60-inch gauge from 11.89 to 21.74 (average 15.32 inches). Most of the high results were obtained in the first few years, during a period of unusually heavy rainfall.

Results of percolation experiments made by Dickinson and Evans (2) at Hemel Hempstead, with Dalton gauges containing soil covered with 
grass, showed a yearly evaporation of 19.97 inches with a rainfall of 25.55 inches. Similar results were obtained by Greaves (1) at Lea Bridge, turfed soil evaporating 18.14 inches (average of 14 years). Greaves also determined the evaporation from a surface of water, which he found amounted to 20.66 inches per annum. The more recent waterevaporation experiments in St Pancras, London, published by Mill (8) gave, however, much lower results, the average yearly amount (19 harvest years) being only 15.55 inches.

TABLE IV.

Monthly Amounts of Drainage through 20, 40, and 60 inches of Soil. Average 35 years.

\begin{tabular}{|c|c|c|c|c|c|c|c|c|c|c|}
\hline \multirow{2}{*}{$\begin{array}{c}1870-1 \\
\text { to } \\
1904-5\end{array}$} & \multirow{2}{*}{ Rainfall } & \multicolumn{3}{|c|}{ Drainage } & \multicolumn{3}{|c|}{ Drainage per cent. of rain } & \multicolumn{3}{|c|}{ Evaporation } \\
\hline & & $\begin{array}{c}20 \text {-inch } \\
\text { gauge }\end{array}$ & $\begin{array}{l}\text { 40-inch } \\
\text { gauge }\end{array}$ & $\begin{array}{c}60 \text {-inch } \\
\text { gange }\end{array}$ & $\begin{array}{l}\text { 20-inch } \\
\text { gauge }\end{array}$ & $\begin{array}{l}\text { 40-inch } \\
\text { gauge }\end{array}$ & $\begin{array}{l}60 \text {-inch } \\
\text { gauge }\end{array}$ & $\begin{array}{c}20 \text {-inch } \\
\text { gauge }\end{array}$ & $\begin{array}{l}\text { 40-inch } \\
\text { gauge }\end{array}$ & $\begin{array}{c}60 \text {-inch } \\
\text { gauge }\end{array}$ \\
\hline & inches & inches & inches & inches & & & & inches & inches & inches \\
\hline 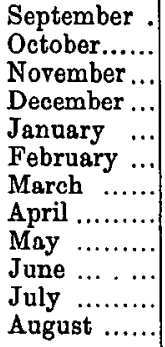 & $\begin{array}{l}2 \cdot 51 \\
3 \cdot 23 \\
2 \cdot 82 \\
2 \cdot 52 \\
2 \cdot 29 \\
1 \cdot 94 \\
1 \cdot 88 \\
1 \cdot 90 \\
2 \cdot 08 \\
2 \cdot 41 \\
2 \cdot 70 \\
2 \cdot 69\end{array}$ & $\begin{array}{l}0.86 \\
1 \cdot 83 \\
2 \cdot 10 \\
2 \cdot 02 \\
1 \cdot 79 \\
1 \cdot 39 \\
0.92 \\
0.50 \\
0.47 \\
0.65 \\
0.68 \\
0.63\end{array}$ & $\begin{array}{l}0 \cdot 81 \\
1 \cdot 80 \\
2 \cdot 15 \\
2 \cdot 14 \\
2 \cdot 02 \\
1 \cdot 53 \\
1 \cdot 06 \\
0 \cdot 57 \\
0.54 \\
0 \cdot 67 \\
0 \cdot 69 \\
0.63\end{array}$ & $\begin{array}{l}0.74 \\
1.64 \\
2.01 \\
2.01 \\
1.92 \\
1.44 \\
1.00 \\
0.53 \\
0.49 \\
0.64 \\
0.65 \\
0.58\end{array}$ & $\begin{array}{l}34 \cdot 3 \\
56 \cdot 7 \\
74 \cdot 5 \\
80 \cdot 2 \\
78 \cdot 2 \\
71 \cdot 7 \\
48 \cdot 9 \\
26 \cdot 3 \\
22 \cdot 6 \\
27 \cdot 0 \\
25 \cdot 2 \\
23 \cdot 4\end{array}$ & $\begin{array}{l}32 \cdot 3 \\
55 \cdot 7 \\
76 \cdot 2 \\
84 \cdot 9 \\
88 \cdot 2 \\
78 \cdot 9 \\
56 \cdot 4 \\
30 \cdot 0 \\
26 \cdot 0 \\
27 \cdot 8 \\
25 \cdot 6 \\
23 \cdot 4\end{array}$ & $\begin{array}{l}29 \cdot 5 \\
50 \cdot 8 \\
71 \cdot 3 \\
79 \cdot 8 \\
83 \cdot 8 \\
74 \cdot 2 \\
53 \cdot 2 \\
27 \cdot 9 \\
23 \cdot 6 \\
26 \cdot 6 \\
24 \cdot 1 \\
21 \cdot 6\end{array}$ & $\begin{array}{l}1.65 \\
1.40 \\
0.72 \\
0.50 \\
0.50 \\
0.55 \\
0.96 \\
1.40 \\
1.61 \\
1.76 \\
2.02 \\
2.06\end{array}$ & $\begin{array}{l}1 \cdot 70 \\
1 \cdot 43 \\
0.67 \\
0.38 \\
0.27 \\
0 \cdot 41 \\
0.82 \\
1 \cdot 33 \\
1 \cdot 54 \\
1 \cdot 74 \\
2 \cdot 01 \\
2 \cdot 06\end{array}$ & $\begin{array}{l}1.77 \\
1.59 \\
0.81 \\
0.51 \\
0.37 \\
0.50 \\
0.88 \\
1.37 \\
1.59 \\
1.77 \\
2.05 \\
2.11\end{array}$ \\
\hline $\begin{array}{l}\text { Sept._Dec. } \\
\text { Jan._April } \\
\text { May-Aug. }\end{array}$ & $\begin{array}{r}11 \cdot 08 \\
8.01 \\
9 \cdot 88\end{array}$ & $\begin{array}{l}6 \cdot 81 \\
4 \cdot 60 \\
2 \cdot 43\end{array}$ & $\begin{array}{l}6 \cdot 90 \\
5 \cdot 18 \\
2 \cdot 53\end{array}$ & $\begin{array}{l}6 \cdot 40 \\
4 \cdot 89 \\
2 \cdot 36\end{array}$ & $\begin{array}{l}61 \cdot 5 \\
57 \cdot 4 \\
24 \cdot 6\end{array}$ & $\begin{array}{l}62 \cdot 3 \\
64 \cdot 7 \\
25 \cdot 6\end{array}$ & $\begin{array}{l}57 \cdot 8 \\
61 \cdot 1 \\
23 \cdot 9\end{array}$ & $\begin{array}{l}4 \cdot 27 \\
3 \cdot 41 \\
7 \cdot 45\end{array}$ & $\begin{array}{l}4 \cdot 18 \\
2 \cdot 83 \\
7 \cdot 35\end{array}$ & $\begin{array}{l}4 \cdot 68 \\
3 \cdot 12 \\
7 \cdot 52\end{array}$ \\
\hline $\begin{array}{l}\text { Oct.-Mar. } \\
\text { April-Sept. }\end{array}$ & $\begin{array}{l}14 \cdot 68 \\
14 \cdot 29\end{array}$ & $\begin{array}{r}10 \cdot 05 \\
3 \cdot 79\end{array}$ & $\begin{array}{r}10 \cdot 70 \\
3.91\end{array}$ & $\begin{array}{r}10 \cdot 02 \\
3.63\end{array}$ & $\begin{array}{l}68 \cdot 5 \\
26 \cdot 5\end{array}$ & $\begin{array}{l}72 \cdot 9 \\
27 \cdot 4\end{array}$ & $\begin{array}{l}68 \cdot 3 \\
25 \cdot 4\end{array}$ & $\begin{array}{r}4 \cdot 63 \\
10 \cdot 50\end{array}$ & $\begin{array}{r}3 \cdot 98 \\
10 \cdot 38\end{array}$ & $\begin{array}{r}4 \cdot 66 \\
10 \cdot 66\end{array}$ \\
\hline Year...... & $28 \cdot 97$ & $13 \cdot 84$ & $14 \cdot 61$ & $13 \cdot 65$ & $47 \cdot 8$ & $50 \cdot 4$ & $47 \cdot 1$ & $15 \cdot 13$ & $14 \cdot 36$ & $15 \cdot 32$ \\
\hline
\end{tabular}

With regard to monthly percolation the average results set out in Table IV show that the maximum drainage occurs in November, that it gradually decreases until May, after which there is a regular rise to September, followed by a considerable rise in October. The monthly differences between the drainage of the 20-inch gauge and that of the 60 -inch gauge are very regular and are best shown as percentages of 
the rain (Fig. 1). From January to May the 60-inch gauge yields a decreasing excess of drainage over the 20 -inch gauge, whilst from June to December (particularly from September to November) the excess of drainage is from the 20 inch gauge. The differences are very difficult to account for and may be due to variations in temperature and consequently in viscosity (to which, presumably, the 20 -iuch gauge would be the more liable to be infuenced), to barometric pressure, or may be connected with the access, escape, and retention of air which will vary according to the depth of the soil.

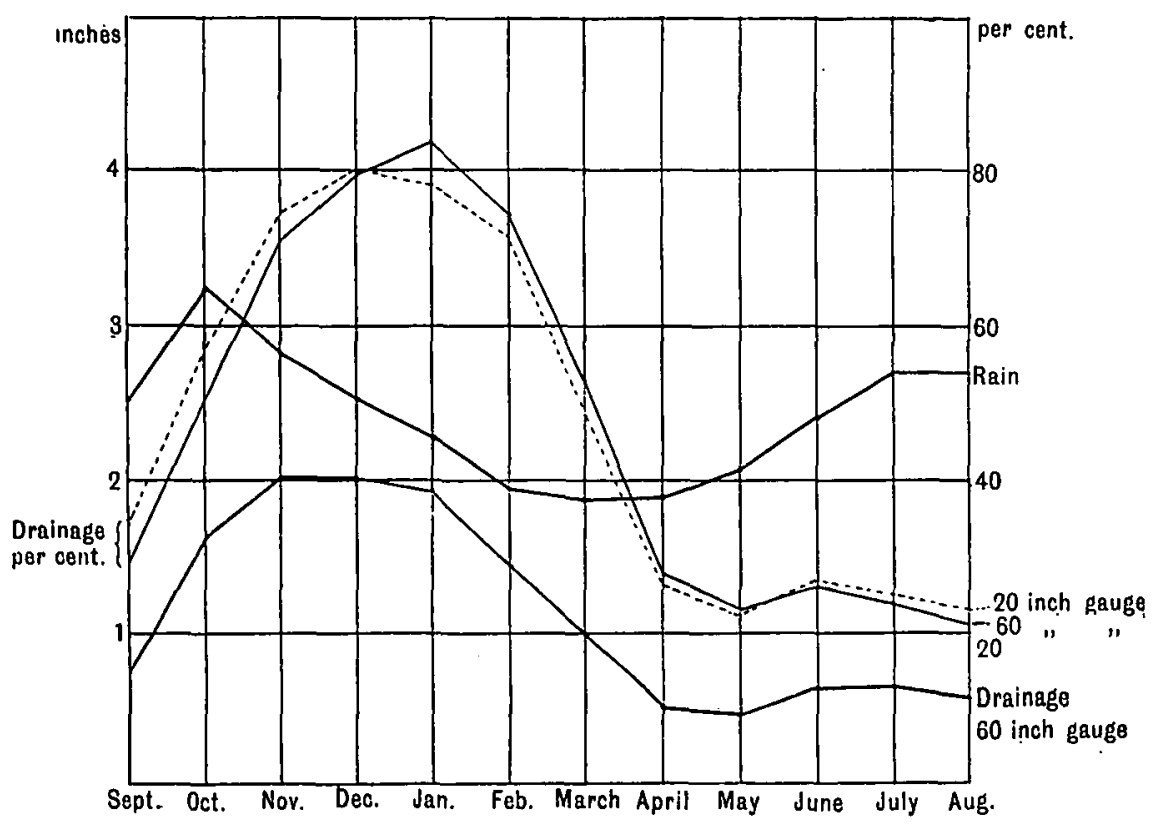

Fro. 1. Rainfall and drainage through 60 inches of soil. Drainage through 20 and 60 inches of soil per cent. of rain. Average 35 years.

In Wollny's (10) experiments with soil from $5 \mathrm{~cm}$. to $30 \mathrm{~cm}$. deep, it was found that the amount of drainage diminished with the depth of the soil up to a certain point $(15 \mathrm{~cm}$. of soil $)$ and then increased. The results are, however, not comparable with those just described, as the deepest soil $(30 \mathrm{~cm}$.) was not much more than half the depth of the 20 -inch gauge. The percentage of water in Wollny's soils increased considerably with the depth of the soil up to $20 \mathrm{~cm}$., and then remained fairly constant. 
The average number of days on which drainage has been recorded is 123 in the case of the 60 -inch gauge. The monthly averages are as follows :

\begin{tabular}{|c|c|}
\hline October ............... & $13 \cdot 0$ \\
\hline November ............. & $14 \cdot 5$ \\
\hline December ............. & $14 \cdot 9$ \\
\hline January............... & $14 \cdot 1$ \\
\hline February $\ldots . . . . . . .$. & $12 \cdot 9$ \\
\hline March ... & $11 \cdot 3$ \\
\hline
\end{tabular}

\begin{tabular}{|c|c|}
\hline April ................. & 8.9 dвув \\
\hline May ....................... & 70, \\
\hline June ................. & 6.5 \\
\hline July .................. & $6 \cdot 8$ \\
\hline August ............... & $5 \cdot 9$ \\
\hline September............. & $7 \cdot 4$ \\
\hline
\end{tabular}

The number of rainy days (see this vol., p. 299) falls from 18 in October to 13 in March, and varies between 12 and 14 in the summer months.

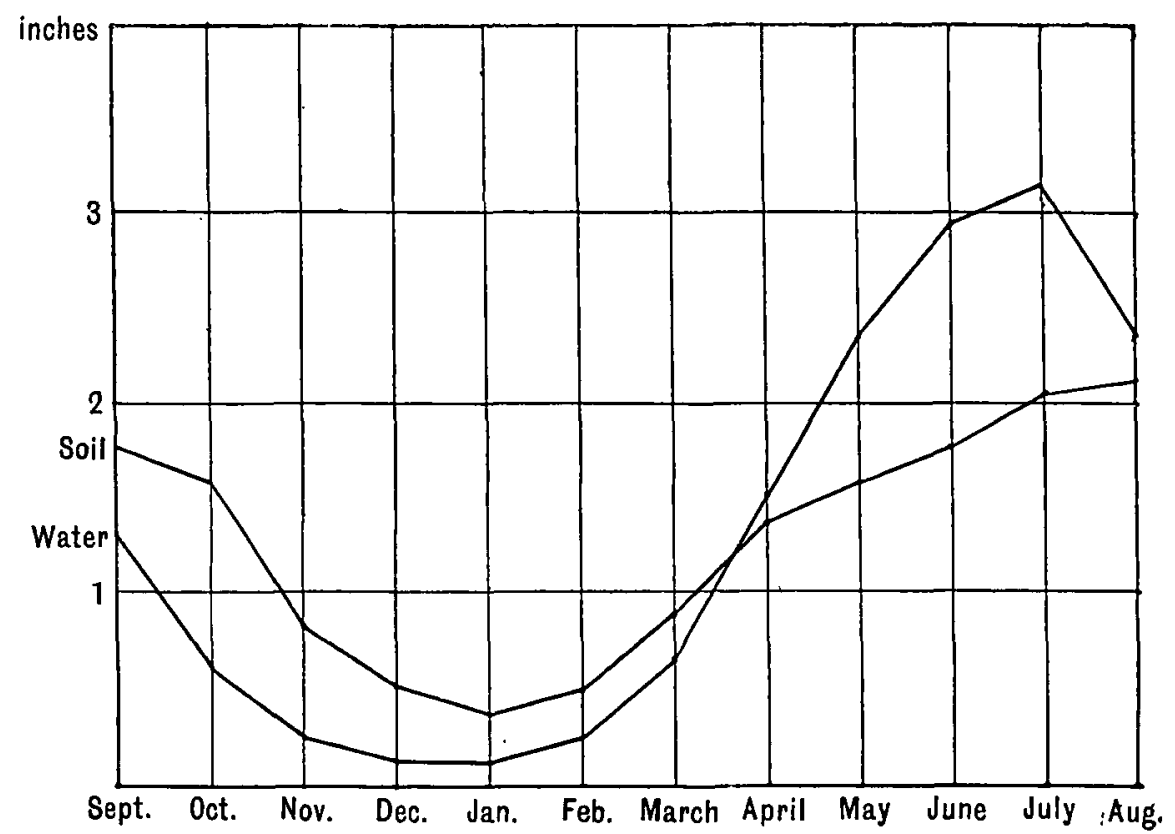

Fic. 2. Estimated evaporation from the soil of the 60-inch gauge; and evaporation from water (Mill).

A comparison of the monthly differences between rain and drainage with the amounts actually evaporated from a surface of water (Mill, loc. cit.), would seem to indicate that from March to September these differences are mainly due to evaporation, and that from October to February a good deal is due to retention by the soil. When, however, we select from the monthly results those which have followed a month at least of high rainfall, it is seen that in most cases the estimated 
amounts of evaporation do not differ greatly from the average. With the exception of October it is probable that the average monthly results indicate almost exclusively evaporation. In October more of the difference between rainfall and drainage would seem to be due to absorption (Fig. 2).

An excess of drainage over the monthly rain has occurred on fifteen occasions, but always from November to March, and chiefly in January and February. On each occasion the excess has been observed in the case of the 40-inch gauge, whilst the 60 - and 20 -inch gauges have only yielded an excess on nine and seven occasions respectively. It is due either to the soil becoming frozen, or to an excess of water at the end of the month not having had time to percolate. Excesses of daily drainage over the amount of rain occur at all times of the year, and may be due to the rate of percolation being for a time slower than the supply of rain, or in some cases perhaps to a rise in temperature resulting in the diminished viscosity of the soil water.

It will now be desirable to consider the effects of drought and of high rainfall on the amounts of drainage and evaporation.

The total rainfall of January and February, 1893, was above the average, and the daily records indicate that the soil of the gauges was saturated at the end of each of these months. In fact there was on March 1 a large excess of drainage (0.259 inch through 20-inch gauge) over the rainfall $(0.117 \mathrm{inch})$ owing to the excess of water not having had time to percolate. During the remainder of March (2-31) the rainfall was only 0.307 inch (making a total of $0.424 \mathrm{inch}$ ), and of this amount 0.124 inch, or 40 per cent., percolated. The evaporation for the whole month as indicated by the difference between rain and drainage would be only 9.7 per cent. of the rain; or, when the first day is excluded, 60 per cent. This is a decidedly high amount, due in part to the very large amount of sunshine-199 hours as against the average of 118 hours (see this rol., p. 299). During the next three months there were only 2.47 inches of rain and no drainage at all. In July, 3 inches of rain fell, but owing to the dried-up condition of the soil there was again practically no drainage $(0.003 \mathrm{inch})$, and even the 0.64 inch which fell in the first three days of August failed to give drainage. The soil was, however, by this time again approaching a state of saturation and on August 5, with 0.25 inch of rain, 31 per cent. $(=0.077$ inch $)$ percolated through the 20-inch gauge. From August 6 to 11, 0.166 inch of rain fell but owing to evaporation there was again no drainage, and only 10 per cent. on the 12th with 0.09 inch of rain. After a week's interval of 
fine days there were four rainy days on which altogether an inch of rain fell, with, however, only 0.03 inch of drainage. In the whole month of August there were 2.38 inches of rain of which only 4.9 per cent. percolated through the 20 -inch gauge and much less through the other gauges; and it was not until the middle of October that regular drainage recommenced.

The results from March 2 may be summarized as follows:

\begin{tabular}{|c|c|c|c|}
\hline \multirow[b]{2}{*}{1893} & \multirow{2}{*}{$\begin{array}{l}\text { Rain } \\
\text { inches }\end{array}$} & \multicolumn{2}{|c|}{ Drainage (20-inch gauge) } \\
\hline & & inches & per cent. \\
\hline March 2 to July $31 . . . . . . . . .$. & $5 \cdot 78$ & 0.127 & $2 \cdot 2$ \\
\hline , , , Aug. 31........... & $8 \cdot 16$ & 0.244 & $3 \cdot 0$ \\
\hline , , Sept. $30 \ldots \ldots \ldots \ldots$ & $9 \cdot 30$ & 0.244 & $2 \cdot 6$ \\
\hline October $1-31 \ldots \ldots \ldots \ldots \ldots \ldots$ & $4 \cdot 46$ & $2 \cdot 749$ & $61 \cdot 6$ \\
\hline
\end{tabular}

The rainfall March-September was rather more than half the average amount.

Another period of drought, shorter than that just described, occurred in June and July, 1904. The rainfall of the previous months since February had been low, and in May, although 2.15 inches of rain fell, the drainage only amounted to 0.057 through 20 , and 0.100 inch through 60 inches of soil. From June 1 to June 10 the rainfall was 0.155 inch and the drainage 0.035 and 0.059 inch respectively. On the 14th 0.284 inch fell, but there was no drainage. From that date to the end of the month the rain only amounted to 0.363 inch, whilst the 20and 60 -inch gauges gave 0.003 and 0.023 inch of drainage. The dry weather continued until July 25, the rain from the 1st to 24th only amounting to 0.35 inch, most of which fell on the first three days. On July 25, 1.44 inches of rain fell, and drainage was found in the cylinders of the gauges amounting to 0.217 inch in the case of the 20-and 0.185 inch in the 60 -inch gauge, corresponding with 15 and 13 per cent. of the rainfall. In this case the difference between rain and drainage, 1.218 inches in the 20 -inch gauge and 1.250 inches in the 60-inch gauge, would no doubt be due to a great extent to retention by the unusually dry soil. But loss by evaporation was no doubt considerable, the amount of sunshine during the month being much above the average.

With heavy rainfall in the summer we have, coincidently, high percentages of drainage, but the effect of the rapid evaporation from the soil soon shows itself. In June, 1903, after an average rainfall in May, there was a fall of $6 \cdot 12$ inches, of which 4.81 inches, or nearly 79 per cent. percolated through 20 inches of soil. In July, the rainfall was 4.09 inches, very considerably over the average, and the percolation 
in the 20-inch gauge was 1.82 inch, or 44 per cent. In August there was again a great excess of rain ( 3.96 inches) and also an excess of drainage (1.35 inches), but the percentage of drainage fell to 34 per cent. All these figures are abnormally high, but they show the great reduction in the relation of drainage to rain in the summer months. In September, 1903 , the rainfall was still somewhat in excess of the average (2.75 inches), whilst the drainage $(0.87$ inch) was quite normal for the month. The very high rainfall in October, amounting to 6.32 inches, resulted in 5.12 inches of drainage through 20 inches of soil, corresponding with 82 per cent., or about 4 per cent. more than in June with a similar rainfall.

Notwithstanding the wet condition of the soil during this period it will be seen that the amount of evaporation was, on the whole, about the same as under average conditions.

\section{Composition of the Drainage.}

\section{Nitrogen as Nitrates.}

In a previous paper (this vol. p. 288) it was shown that the rain supplies annually to the soil about five pounds of nitrogen. Of this amount about four pounds represent nitrates and ammonia which would be rapidly nitrified in the soil, and the rest, about one pound, represents organic compounds which may be either more or less readily nitrified than the organic nitrogen of the soil. In any case the total amount is very small as compared with the amounts found in the drainage through the soil of the gauges.

During the last 28 years the average loss of nitrogen in the gauges has been 31.4 lbs. per acre per annum. The annual losses (see Table V) vary from year to year considerably, partly owing to differences in the rainfall and partly to the distribution of the rain. There is, in addition, as will be shown later on, a slight tendency for the nitrates to decrease, but this only manifests itself when successive averages of several years are compared. The yearly amounts of nitrogen in the drainage of the 60 -inch gauge have varied from 61 to $15 \mathrm{lbs}$. with the highest recorded rainfall in 1878-9 (41.05 inches) and the lowest rainfall in 1897-8 (19.51 inches). Both years were preceded by years of high rainfall. In 1898-9 when the rainfall was, for a second year, unusually low, the 60 -inch gauge lost nearly 31 lbs. of nitrogen; and in 1899-1900 nearly $38 \mathrm{lbs}$. The very low results of $1897-8$ are partly due to the 
complete washing-out to which the gauges were subjected the year before, when the 60 -inch gauge lost $41.4 \mathrm{lbs}$. of nitrogen. It is probable, however, that the 19 years between the maximum and minimum losses have helped to increase the difference.

TABLE V.

Yearly Amounts of Nitrogen as Nitrates in the Drainage through 20, 40, and 60 inches of Soil.

\begin{tabular}{|c|c|c|c|c|c|c|c|}
\hline \multirow{2}{*}{$\begin{array}{l}\text { Sept. } 1 \\
\text { to } \\
\text { Aug. } 31\end{array}$} & \multirow[b]{2}{*}{ Rainfall } & \multicolumn{3}{|c|}{ Drainage } & \multicolumn{3}{|c|}{ Nitrogen, lbs. per acre } \\
\hline & & $\begin{array}{c}\text { Soil } \\
20 \text { inches } \\
\text { deep }\end{array}$ & $\begin{array}{c}\text { Soil } \\
40 \text { inches } \\
\text { deep }\end{array}$ & $\begin{array}{c}\text { Soil } \\
60 \text { inches } \\
\text { deep }\end{array}$ & 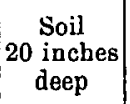 & $\begin{array}{c}\text { Soil } \\
40 \text { inches } \\
\text { deep }\end{array}$ & $\begin{array}{c}\text { Soil } \\
60 \text { inches } \\
\text { deep }\end{array}$ \\
\hline & inches & inches & inches & inches & lbs. & lbs. & lbs. \\
\hline $1877-8$ & $32 \cdot 65$ & $14 \cdot 72$ & $16 \cdot 44$ & $14 \cdot 81$ & $44 \cdot 75$ & $39 \cdot 53$ & $45 \cdot 92$ \\
\hline $1878-9$ & $41 \cdot 05$ & $24 \cdot 44$ & $26 \cdot 03$ & $24 \cdot 38$ & $59 \cdot 36$ & $46 \cdot 52$ & $60 \cdot 94$ \\
\hline $1879-80$ & $21 \cdot 36$ & $6 \cdot 89$ & $7 \cdot 39$ & $6 \cdot 50$ & $27 \cdot 03$ & $17 \cdot 87$ & $20 \cdot 19$ \\
\hline $1880-1$ & 36.77 & $22 \cdot 38$ & $22 \cdot 84$ & $21 \cdot 26$ & $57 \cdot 78$ & $44 \cdot 22$ & $49 \cdot 95$ \\
\hline 1881-2 & $32 \cdot 31$ & $15 \cdot 81$ & $16 \cdot 08$ & $14 \cdot 32$ & $32 \cdot 93$ & $31 \cdot 74$ & $35 \cdot 24$ \\
\hline $1882-3$ & $34 \cdot 71$ & $20 \cdot 82$ & $21 \cdot 72$ & $19 \cdot 72$ & $32 \cdot 67$ & $36 \cdot 08$ & $38 \cdot 26$ \\
\hline 1883-4 & $25 \cdot 77$ & $11 \cdot 86$ & $12 \cdot 00$ & $11 \cdot 21$ & $29 \cdot 31$ & $26 \cdot 85$ & $26 \cdot 89$ \\
\hline $1884-5$ & $26 \cdot 78$ & $14 \cdot 82$ & $15 \cdot 14$ & $13 \cdot 98$ & $39 \cdot 55$ & $36 \cdot 71$ & $33 \cdot 86$ \\
\hline $1885-6$ & $31 \cdot 02$ & $17 \cdot 37$ & $18 \cdot 41$ & $16 \cdot 57$ & $34 \cdot 49$ & $32 \cdot 27$ & $34 \cdot 36$ \\
\hline $1886-7$ & $23 \cdot 61$ & $10 \cdot 64$ & $12 \cdot 58$ & $11 \cdot 72$ & $25 \cdot 28$ & $21 \cdot 88$ & $24 \cdot 98$ \\
\hline $1887-8$ & $30 \cdot 50$ & $13 \cdot 96$ & $15 \cdot 58$ & $14 \cdot 67$ & $43 \cdot 10$ & $36 \cdot 90$ & $35 \cdot 67$ \\
\hline $1888-9$ & 30.09 & $14 \cdot 64$ & $15 \cdot 82$ & $14 \cdot 33$ & 31.96 & $29 \cdot 25$ & 30.50 \\
\hline $\begin{array}{l}1889-90 \\
1890-1\end{array}$ & $\begin{array}{l}27 \cdot 43 \\
23 \cdot 41\end{array}$ & $\begin{array}{r}13 \cdot 16 \\
9 \cdot 05\end{array}$ & $\begin{array}{r}13 \cdot 60 \\
9 \cdot 70\end{array}$ & $\begin{array}{r}12 \cdot 74 \\
0.70\end{array}$ & $27 \cdot 61$ & 24.94 & $28 \cdot 41$ \\
\hline $1890-1$ & $23 \cdot 41$ & 9.95 & $9 \cdot 70$ & $9 \cdot 73$ & $25 \cdot 70$ & $19 \cdot 90$ & $22 \cdot 04$ \\
\hline 1891-2 & $29 \cdot 68$ & $16 \cdot 50$ & $17 \cdot 43$ & $16 \cdot 47$ & $29 \cdot 39$ & 28.45 & $33 \cdot 43$ \\
\hline 1892-3 & $24 \cdot 08$ & $11 \cdot 58$ & $12 \cdot 35$ & $12 \cdot 10$ & $22 \cdot 61$ & $20 \cdot 40$ & $23 \cdot 72$ \\
\hline $1893-4$ & $29 \cdot 55$ & $13 \cdot 36$ & $14 \cdot 11$ & $14 \cdot 07$ & 40.94 & $31 \cdot 53$ & $34 \cdot 52$ \\
\hline $1894-5$ & $28 \cdot 94$ & $15 \cdot 50$ & $16 \cdot 95$ & 16.31 & $37 \cdot 12$ & $33 \cdot 18$ & $34 \cdot 36$ \\
\hline $1895-6$ & $24 \cdot 37$ & $9 \cdot 84$ & $10 \cdot 75$ & $10 \cdot 35$ & $23 \cdot 18$ & $22 \cdot 77$ & $22 \cdot 78$ \\
\hline $1896-7$ & $37 \cdot 24$ & $21 \cdot 88$ & $23 \cdot 86$ & $22 \cdot 80$ & $36 \cdot 62$ & $35 \cdot 77$ & $41 \cdot 40$ \\
\hline $1897-8$ & $19 \cdot 51$ & 5.95 & $6 \cdot 66$ & 6.47 & $18 \cdot 20$ & $13 \cdot 95$ & $15 \cdot 01$ \\
\hline $1898-9$ & $24 \cdot 70$ & $11 \cdot 99$ & $12 \cdot 48$ & $12 \cdot 48$ & $33 \cdot 23$ & $28 \cdot 65$ & $30 \cdot 91$ \\
\hline $1899-1900$ & 31.02 & $16 \cdot 33$ & 16.93 & 17.02 & $37 \cdot 00$ & $33 \cdot 85$ & $37 \cdot 68$ \\
\hline $1900-1$ & $24 \cdot 30$ & $10 \cdot 91$ & $12 \cdot 35$ & $11 \cdot 92$ & $33 \cdot 68$ & $28 \cdot 24$ & $29 \cdot 26$ \\
\hline 1901-2 & $23 \cdot 26$ & $8 \cdot 75$ & $9 \cdot 32$ & $9 \cdot 44$ & $29 \cdot 12$ & $21 \cdot 65$ & $22 \cdot 11$ \\
\hline $1902-3$ & $31 \cdot 25$ & $16 \cdot 33$ & $17 \cdot 09$ & $17 \cdot 59$ & $33 \cdot 70$ & 30.98 & $32 \cdot 73$ \\
\hline $1903-4$ & $31 \cdot 52$ & $17 \cdot 68$ & $17 \cdot 92$ & $18 \cdot 29$ & $16 \cdot 38$ & 20.87 & $24 \cdot 36$ \\
\hline $1904-5$ & $25 \cdot 30$ & $10 \cdot 10$ & $10 \cdot 45$ & $10 \cdot 36$ & $23 \cdot 25$ & $21 \cdot 58$ & $22 \cdot 08$ \\
\hline
\end{tabular}

The amount of water percolating through the soils of the gauges reaches its maximum, as already shown, in November, the highest rainfall being in October. The drainage then decreases until April, which is the month of minimum drainage; increases very slightly in May and June (Table VI). After a slight fall in July, the drainage again increases until November. 
N. H. J. MILLER

\begin{tabular}{|c|c|c|c|c|c|c|}
\hline \multirow[b]{2}{*}{$\overbrace{0}^{\circ}$} & \multirow{3}{*}{\multicolumn{2}{|c|}{ 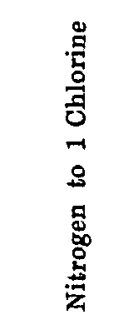 }} & 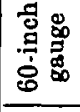 & 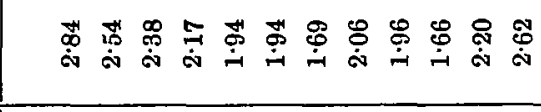 & ڤึ & $\stackrel{\vec{\omega}}{\vec{\omega}}$ \\
\hline & & & 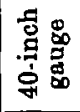 & 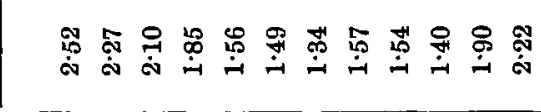 & $\stackrel{\mathscr{\infty}}{\stackrel{\infty}{\sim}} \underset{\sim}{-\infty}$ & $\stackrel{\vec{\Phi}}{-\vec{\omega}}$ \\
\hline 胥 & & & 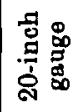 & 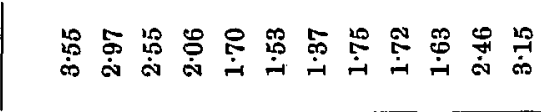 & 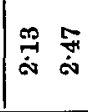 & 芯 \\
\hline है & & & 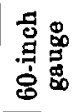 & 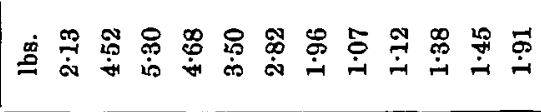 & 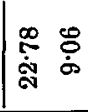 & 崖 \\
\hline $\begin{array}{l}\text { के } \\
\text { के }\end{array}$ & & 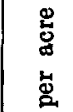 & 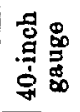 & 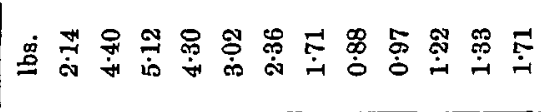 & $\mid \begin{array}{ll}-1 \\
\dot{\phi}\end{array}$ & 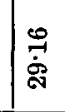 \\
\hline हूँ & 焉 & & 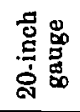 & 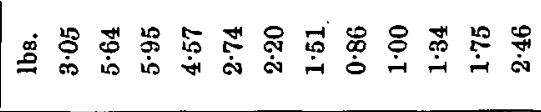 & 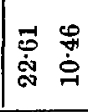 & 商 \\
\hline ڤ & 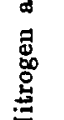 & & 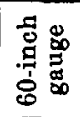 & 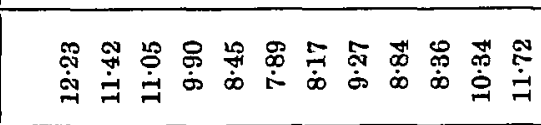 & 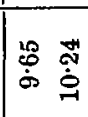 & $\begin{array}{l}\vec{\infty} \\
\dot{0}\end{array}$ \\
\hline \begin{tabular}{l}
5 \\
\multirow{2}{*}{}
\end{tabular} & & : & 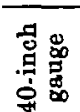 & 导 & 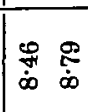 & 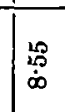 \\
\hline 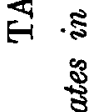 & & & 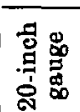 & 号 & 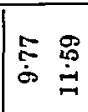 & 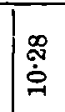 \\
\hline $\begin{array}{l}3 \\
\frac{5}{4} \\
8\end{array}$ & & & 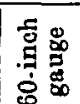 & 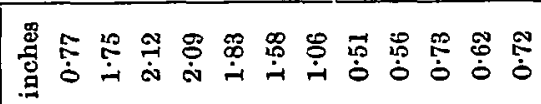 & 要 & 岸 \\
\hline 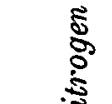 & & 苋 & 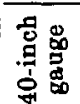 & 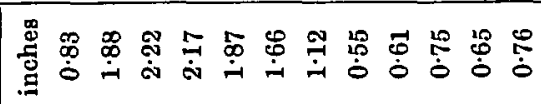 & 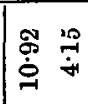 & 总 \\
\hline$b$ & & & 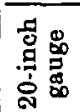 & 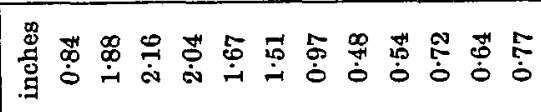 & 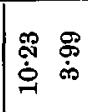 & 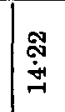 \\
\hline हूँ & & 莺 & & 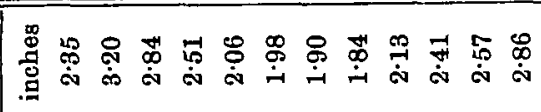 & 栗 & 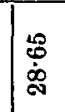 \\
\hline$\overbrace{\tilde{4}}^{5}$ & & & & 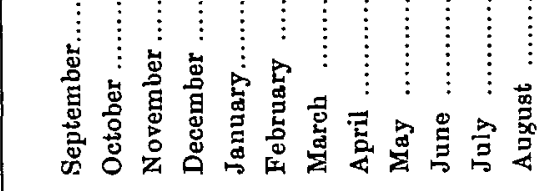 & 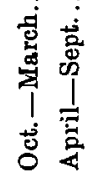 & 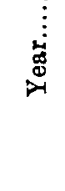 \\
\hline
\end{tabular}


The monthly results set out in Table VI show that the highest amounts of nitrogen per million in the drainage through 20 and 60 inches of soil occur in September, whilst the lowest amounts are found in February. The extremes are 16.05 and 6.44 for the 20-inch gauge and 12.23 and 7.89 per million in the deepest gauge. The amounts for the year are quite similar in the two gauges, so that the monthly differences are merely due to the mode of distribution. The soil water in the deeper gauge evidently becomes more mixed than that of the 20-inch gauge (Fig. 3).

As regards the amounts of nitrogen withdrawn from the soil in the different months, the lowest, unlike the minimum concentration, is in April. This is followed by a gradual and fairly regular rise until September, and then by a rapid rise until November, when the maximum loss occurs. This is succeeded by a fall until April.

The relation of nitric nitrogen to the quantity of the drainage is somewhat complicated. In the first place, the amount of nitrification will depend on the temperature and on the degree of moisture in the upper portions of the soil. Then to completely extract the whole of recently-produced nitrates would of course require an amount of rain more than sufficient to expel the whole of the water existing in the soil. Results of determinations of moisture made in Broadbalk soils (4) in 1869 after much rain, showed that when saturated the soil of the unmanured plot contained down to 3 feet 23 per cent. of water. This would be equivalent to abont 7.6 inches of water in the soil of the 20 -inch gauge, 15.2 inches in the 40 -inch, and 22.8 inches in the 60 -inch gauge. To completely extract the gauges would, therefore, require considerably more rain than is generally realised. The comparatively low amounts of nitric nitrogen in the drainage of the early summer months, taken in conjunction with the small amounts of drainage, indicate that most of the drainage in these months is derived from the subsoil. It is not until September that the waters richest in nitrates are obtained, whilst high results continue to be obtained throughout October and November, notwithstanding the diluted condition of the drainage at this time and the comparative inactivity of nitrifying organisms.

It will be noticed that whilst the total drainage of the 20 -inch and 60-inch gauges are almost the same, that of the 40-inch gauge is distinctly higher. The total nitric nitrogen in the drainage of the 20- and 60-inch gauges also differs by rather more than $1 \mathrm{lb}$. per acre, whilst that of the 40 -inch gauge is not higher, as might be expected from the higher 
drainage, but about $3 \mathrm{lbs}$, or 10 per cent. lower than the mean of the other two gauges. The difference is still more marked when the

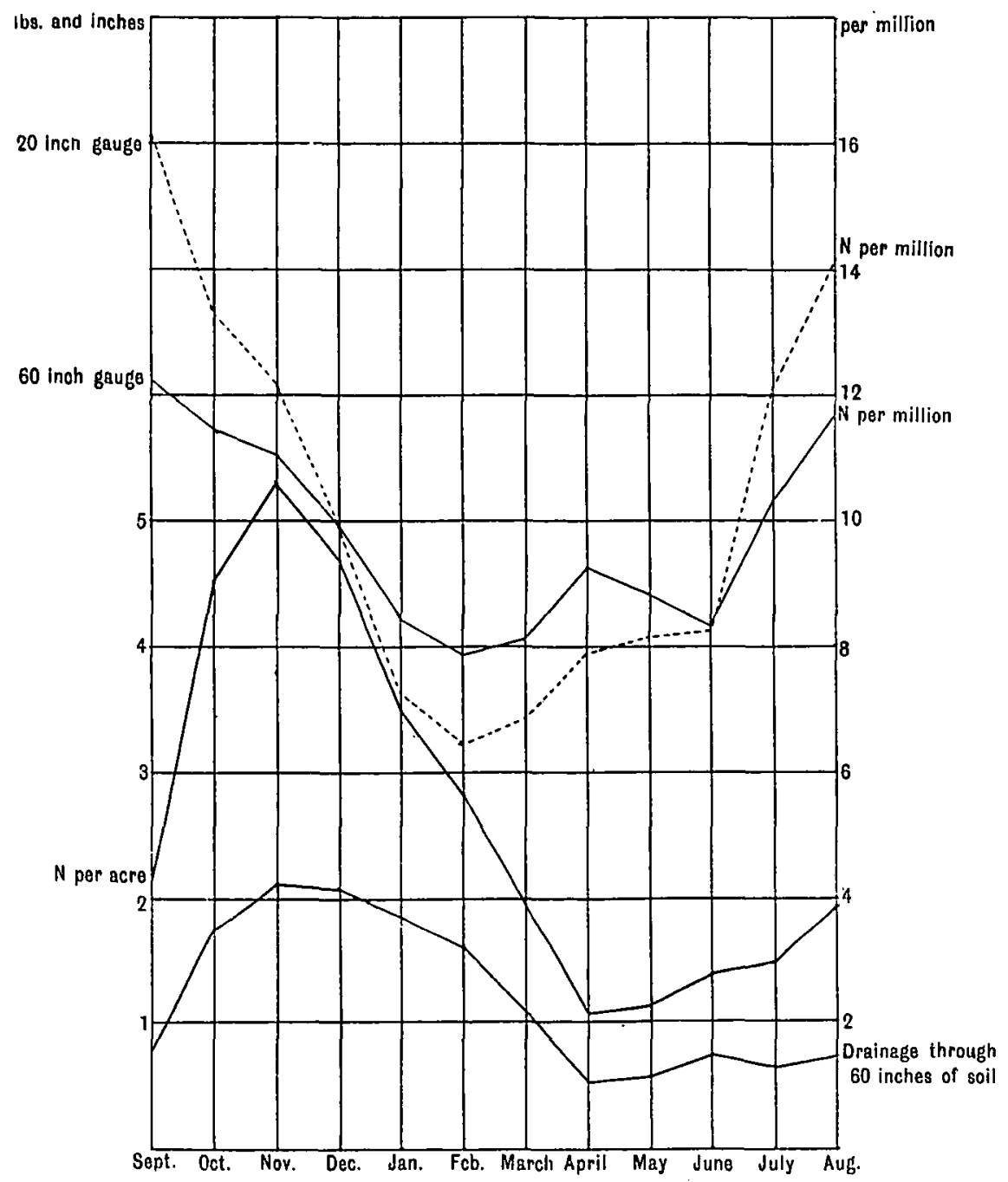

Fra. 3. Drainage through 60 inches of soil, and loss of nitrogen per acre. Nitrogen per million in the drainage through 20 and 60 inches of soil. Average 28 years.

nitrogen is considered in relation to chlorine in the three drainage waters (Table VI). The 20 -inch and 60 -inch gauges give almost identical results, the 40 -inch gauge a much lower result (for the year). 
A good example of the effect of drought on the composition of subsequent drainage is afforded by the dry period in 1893, already referred to in connection with the percolation and evaporation.

\section{TABLE VII.}

Effect of Dry Weather on the Amount and Composition of subsequent Drainage. (20-inch Gauge.)

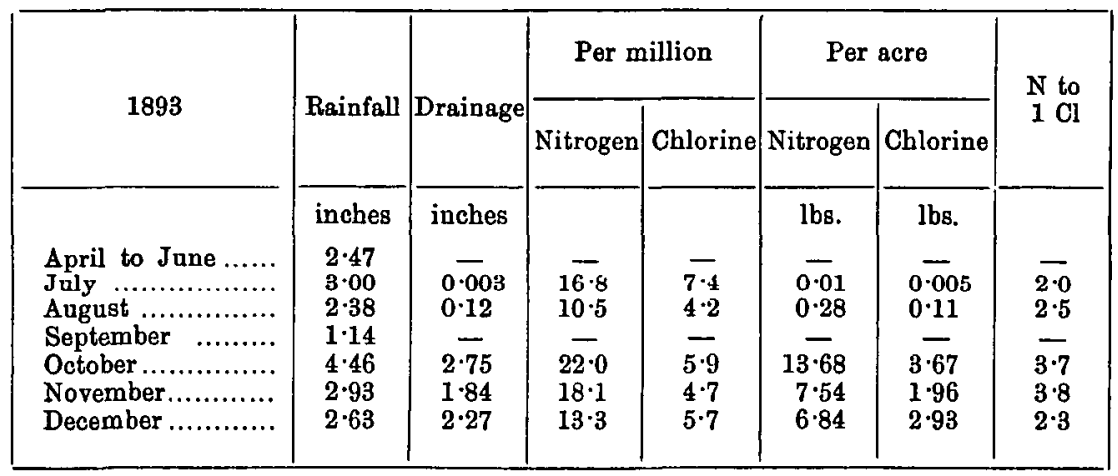

The raiufall since August, 1892, had been fairly normal with the exception of March, when the rain and drainage amounted respectively to 0.42 and 0.38 inch. The nitrates and chlorine were rather below the average, the former decreasing irregularly from 14.9 in September to 5.4 in March, the latter from 5.5 to 3.0 per million. The renewed drainage of July was probably, in view of the very high chlorine results, surface water concentrated by evaporation. In August the amount of chlorine shows that the drainage was at any rate not more concentrated than usual at this time of the year, whilst the decrease in the, still high, amount of nitric acid would indicate more subsoil water, and hence normal drainage. The next results, in October (the highest of all but two recorded for this month), clearly indicate that the water which had been near the surface during the summer months was now passing through the soil. The nitrogen then decreased until by January the drainage contained about the average amount (7.3 per million).

The only higher amounts of nitrogen recorded occurred in two consecutive months, September and October, 1887, after a year of very low rainfall (23.61 inches).

With average losses of 29 to 33 lbs. of nitrogen per acre, or deducting $5 \mathrm{lbs}$. for nitrogen contributed by rain, of 24 to $28 \mathrm{lbs}$., it would be 
natural to expect some indication of a gradual exhaustion of the unmanured soil after a period of nearly 30 years. The results recorded in Table V, which gives the annual loss in each year, show, however, such wide differences, depending on the amount of rain and drainage, that it cannot be said that we have absolutely certain indication of actual or approaching exhaustion. In some of the early years the amounts of nitrogen were very large, but so were also the amounts of drainage. The following summary, giving averages for four periods of seven years, shows very little indication of a continuous falling off, especially when the amount of drainage is taken into account.

\section{TABLE VIII.}

Average Losses of Nitrogen in the Drainage through 20, 40, and 60 inches of Soil during Four Periods of Seven Years.

\begin{tabular}{|c|c|c|c|c|c|c|c|}
\hline \multirow{2}{*}{$\begin{array}{l}\text { Harvest years } \\
\text { Sept. 1-Aug. } 31\end{array}$} & \multirow[b]{2}{*}{ Rainfall } & \multicolumn{3}{|c|}{ Drainage } & \multicolumn{3}{|c|}{ Nitrogen as Nitrates per acre } \\
\hline & & $\mid \begin{array}{c}\text { Soil } \\
20 \text { inches } \\
\text { deep }\end{array}$ & $\left|\begin{array}{c}\text { Soil } \\
40 \text { inches } \\
\text { deep }\end{array}\right|$ & $\begin{array}{c}\text { Soil } \\
60 \text { inches } \\
\text { deep }\end{array}$ & $\begin{array}{c}\text { Soil } \\
20 \text { inches } \\
\text { deep }\end{array}$ & $\begin{array}{c}\text { Soil } \\
40 \text { inches } \\
\text { deep }\end{array}$ & $\begin{array}{c}\text { Boil } \\
60 \text { inches } \\
\text { deep }\end{array}$ \\
\hline & inches & inches & inches & inches & lbs. & lbs. & lbs. \\
\hline $\begin{array}{l}1877-8 \text { to } 1883-4 \ldots \\
1884-5 \text { to } 1890-1 \ldots \\
1891-2 \text { to } 3897-8 \ldots \\
1898-9 \text { to } 1904-5 \ldots\end{array}$ & $\begin{array}{l}32 \cdot 09 \\
27 \cdot 55 \\
<7 \cdot 62 \\
27 \cdot 33\end{array}$ & $\begin{array}{l}16 \cdot 70 \\
13 \cdot 51 \\
13 \cdot 52 \\
13 \cdot 16\end{array}$ & $\begin{array}{l}17 \cdot 50 \\
14 \cdot 40 \\
14 \cdot 59 \\
18 \cdot 79\end{array}$ & $\begin{array}{l}16 \cdot 03 \\
13 \cdot 39 \\
14 \cdot 08 \\
13 \cdot 87\end{array}$ & $\begin{array}{l}40 \cdot 55 \\
32 \cdot 53 \\
29 \cdot 72 \\
29 \cdot 48\end{array}$ & $\begin{array}{l}34 \cdot 69 \\
28 \cdot 84 \\
26 \cdot 58 \\
26 \cdot 55\end{array}$ & $\begin{array}{l}39 \cdot 62 \\
29 \cdot 97 \\
29 \cdot 32 \\
28 \cdot 45\end{array}$ \\
\hline
\end{tabular}

TABLE IX.

Relation of Nitrogen as Nitrates to Chlorine in the Drainage during Four Periods of Seven Years.

\begin{tabular}{|c|c|c|c|}
\hline \multirow{2}{*}{$\begin{array}{l}\text { Harvest years } \\
\text { Sept. 1-Aug. } 31\end{array}$} & \multicolumn{3}{|c|}{ Nitrogen to Chlorine $=1$} \\
\hline & $\begin{array}{l}\text { 20-inch } \\
\text { gauge }\end{array}$ & $\begin{array}{l}40 \text {-inch } \\
\text { gange }\end{array}$ & $\begin{array}{l}\text { 60-inch } \\
\text { gauge }\end{array}$ \\
\hline $\begin{array}{l}1877-8 \text { to } 1883-4 \ldots \ldots \\
1884-5 \text { to } 1890-1 \ldots \ldots \\
1891-2 \text { to } 1897-8 \ldots \ldots \\
1898-9 \text { to } 1904-5 \ldots \ldots\end{array}$ & $\begin{array}{l}2 \cdot 76 \\
2 \cdot 50 \\
2 \cdot 12 \\
1 \cdot 67\end{array}$ & $\begin{array}{l}2 \cdot 22 \\
2 \cdot 02 \\
1 \cdot 73 \\
1 \cdot 45\end{array}$ & $\begin{array}{l}2 \cdot 82 \\
2 \cdot 33 \\
2 \cdot 06 \\
1 \cdot 64\end{array}$ \\
\hline
\end{tabular}

Journ, of Agric. Sci: ! 
When, however, the nitric nitrogen is considered in relation to the chlorine, the average amounts of which in periods of several years closely resemble the averages in rain, there is distinct evidence of a decline in the amount of nitrates produced (Table IX).

Then, again, by selecting two years of heavy rainfall, each preceded by a year of low rainfall, indications of a marked reduction in the loss of nitrogen are obtained.

\section{TABLE X.}

Loss of Nitrogen in two years of High Rainfall and Drainage.

\begin{tabular}{|c|c|c|c|c|}
\hline & & \multicolumn{3}{|c|}{ Nitrogen per acre } \\
\cline { 3 - 5 } & Rainfall & $\begin{array}{c}\text { 20-inch } \\
\text { gauge }\end{array}$ & $\begin{array}{c}40 \text {-inch } \\
\text { gauge }\end{array}$ & $\begin{array}{c}\text { 60-inch } \\
\text { gauge }\end{array}$ \\
\hline & inches & lbs. & lbs. & lbs. \\
$1880-1 \ldots \ldots$. & 36.77 & $57 \cdot 78$ & 44.22 & 49.95 \\
$1896-7 . . .$. & 37.24 & 36.62 & $35 \cdot 77$ & 41.40 \\
\hline
\end{tabular}

It is not an easy matter in view of the irregularity in the Rothamsted soils to obtain a very accurate estimate of the losses actually undergone by the soil of the gauges, and this difficulty is considerably increased by the incompleteness of the analysis of the drainuge during the first seven years of the experiments. The following estimate is perhaps as correct as is possible under the circumstances.

\section{TABLE XI.}

Loss of Nitrogen in the Soils of the three Gauges during the last 35 years.

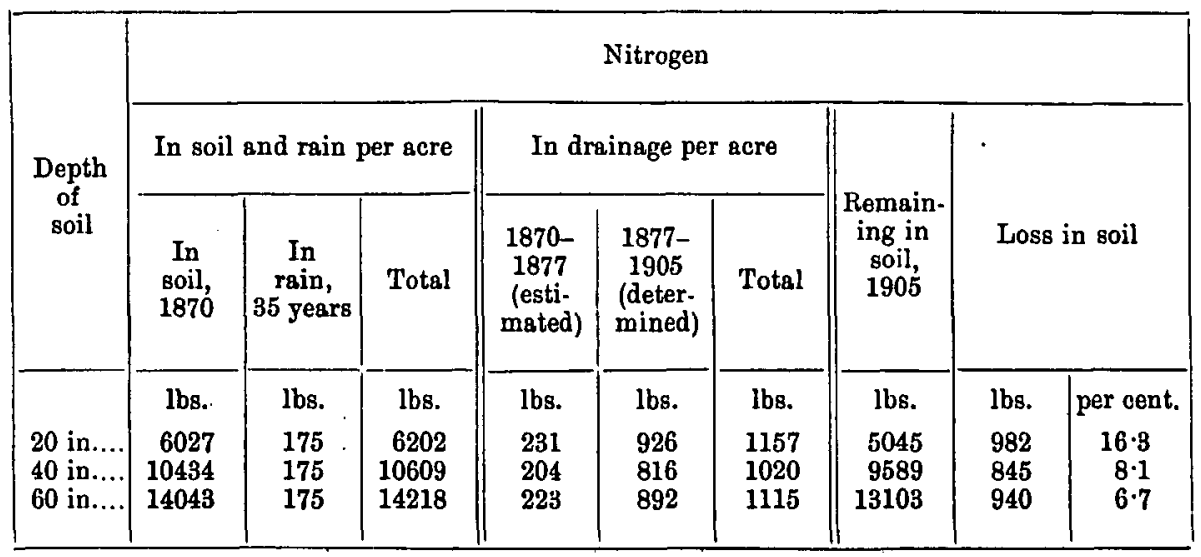


The losses of nitrogen are, therefore, considerable, but even in the case of the 20-inch gauge between eight and nine-tenths remain. It is of course possible that fixation of free nitrogen is going on all the time, and that the soil is really losing less nitrogen than indicated by the above results. We have no complete evidence either for or against fixation ${ }^{1}$. It is at any rate evident that plenty of nitrifiable nitrogen still remains in the soil and that the conditions remain favourable to nitrification. Determinations of lime made from September, 1896, to April, 1898, in the drainage from each gauge show that the loss of calcium carbonate amounted in a year of normal rainfall (with, however, a low amount of drainage) to about 300 lbs. in the case of the 60 -inch gauge, and somewhat less in the other gauges. This would amount to $10,500 \mathrm{lbs}$. of calcium carbonate in the 35 years, or rather more than 10 per cent. of the total estimated amount?. There is no doubt, however, that the losses would be greater in the early years of the experiment when the soil contained more organic matter. Unlike the nitrogen, the loss of calcium slightly increases with the depth of the soil. Rather more than one-fourth to one-third of the total lime in the drainage is required to neutralise the nitric acid present.

\section{The Amounts of Chlorine in the Drainage.}

The yearly amounts of chlorine (Table XII) in the drainage are on the whole similar to the amounts found in the rain of the corresponding years, although in years of low rainfall there may be a deposition of chlorides in the soil, and consequently low amounts in the drainage, as in the year 1879-80. But the chlorides deposited one year appear as

1 In February, 1905, two small samples were taken with a borer from the soil of the 60 -inch gauge to a depth of 9 inches. The fine soil, dried at $100^{\circ}$, contained 0.102 per cent. of nitrogen, corresponding with $2,448 \mathrm{lb}$. per acre. This amount deducted from the estimated amount in the soil in 1870 (see p. 379) indicates a loss of 1056 lbs. in 35 years. This agrees as nearly as can be expected with the estimate in Table XI, and makes it improbable that the soil has acquired any considerable amount of nitrogen from the air, either by fixation of free nitrogen, or by absorption of ammonia, beyond that supplied by rain. It may here be mentioned that for some years, until four or five years ago, a growth of Nostoc was frequently observed on the surface of the 20 -inch gauge. It has been shown by Kossowitsch (Bot. Zeit. 1894, 52, 97) and by Bouilhac (Ann. Agron. 1898, 24, 561) that bacteria exist which in presence of Nostoc fix elementary nitrogen. It is, however, not established that Nostoc is always accompanied by this microbe; and in the present case no material amount of fixation can have taken place, as the growth was always at once removed.

2 For full results relating to calcium in the drainage through the 60 -inch gauge see Proc. R. S. 1905, B. 77, 14 . 
additional amounts in the drainage in other years, so that the averages of several years closely correspond with the average amounts in the rain for the same periods. This is of some interest, since it makes it possible in the case of field drainage, where the amount of percolation is unknown, to calculate from the concentration of the chlorine present, both the amounts of yearly drainage and the total amounts of other constituents. This applies, of course, only to conditions of soil and climate similar to those at Rothamsted. And approximately correct estimates are only to be expected when results extending over a few years are available.

TABLE XII.

Annual Amounts of Chlorine in the Rain and the Drainage through 20, 40, and 60 inches of Soil. Gain or loss of Chlorine in the Soil.

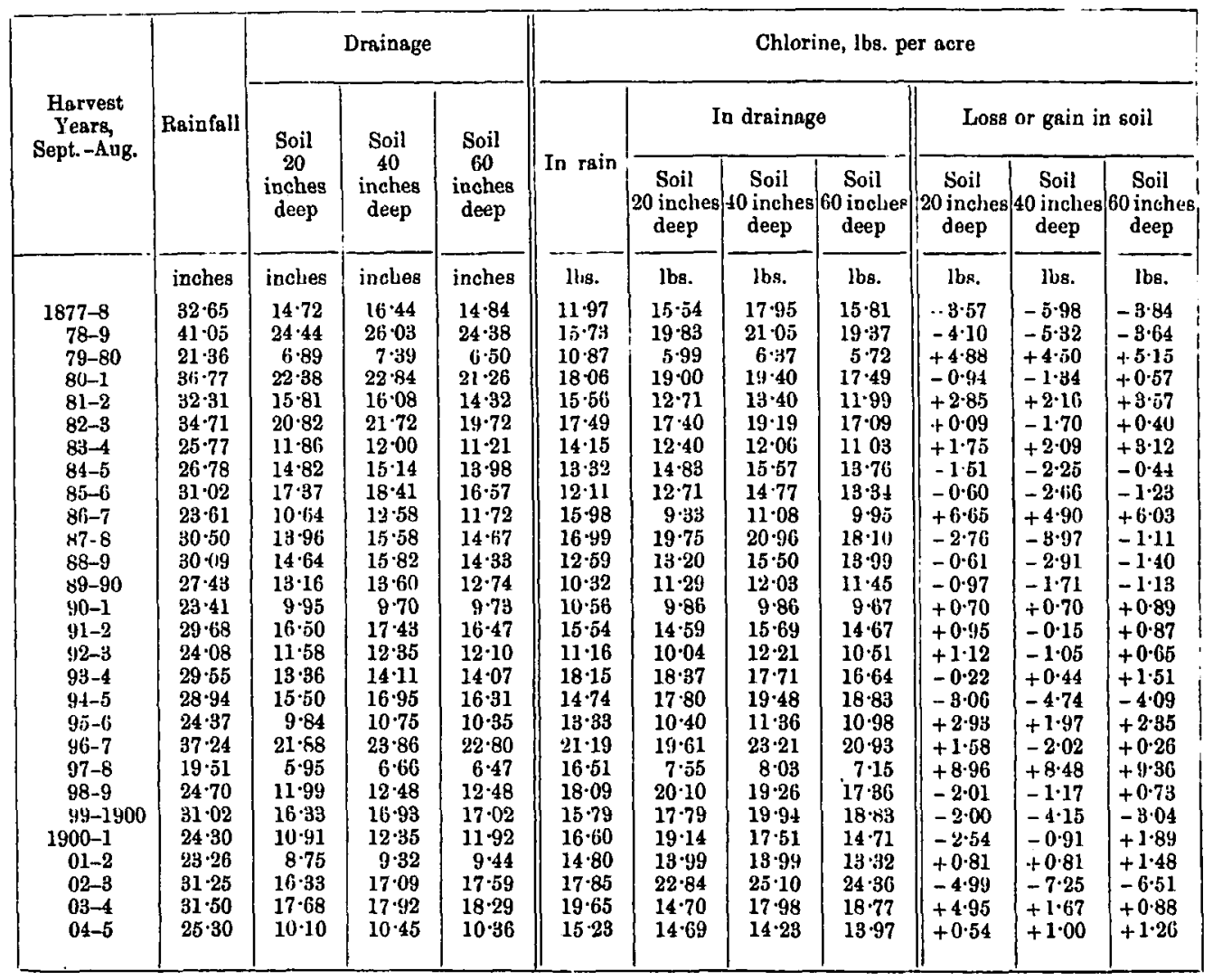


Perhaps the most striking point in connexion with the results relating to chlorine in the drainage is the comparatively slight, although irreguliur, variation in the average amounts per million of water from month to month. The extremes (see Table XIII) occur in June, when

\section{TABLE XIII.}

Monthly Amounts of Chlorine in the Drainage through 20, 40, and 60 inches of Soil. Average 28 years.

\begin{tabular}{|c|c|c|c|c|c|c|c|c|c|c|}
\hline \multirow{3}{*}{$\begin{array}{c}1877-8 \\
80 \\
1004-5\end{array}$} & \multirow{3}{*}{ Rainfull } & \multicolumn{9}{|c|}{ Chlorine } \\
\hline & & \multicolumn{3}{|c|}{ Per million } & \multicolumn{3}{|c|}{ Per acre } & \multicolumn{3}{|c|}{+ or - in rain (per acre) } \\
\hline & & $\begin{array}{l}20 \text {-inch } \\
\text { gauge }\end{array}$ & $\begin{array}{l}\text { 40-inch } \\
\text { gauge }\end{array}$ & $\begin{array}{l}\text { 60-inch } \\
\text { gauge }\end{array}$ & $\begin{array}{c}20 \text {-inch } \\
\text { gauge }\end{array}$ & $\begin{array}{l}\text { 40-inch } \\
\text { gauge }\end{array}$ & $\begin{array}{c}60 \text {-inch } \\
\text { gauge }\end{array}$ & $\begin{array}{c}20 \text {.incb } \\
\text { gauge }\end{array}$ & $\begin{array}{l}\text { 40-inch } \\
\text { gauge }\end{array}$ & $\begin{array}{c}\text { 60-inch } \\
\text { gauge }\end{array}$ \\
\hline 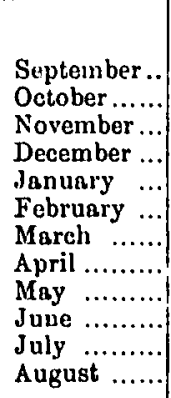 & $\begin{array}{c}\text { inches } \\
2 \cdot 35 \\
3 \cdot 20 \\
2 \cdot 84 \\
2 \cdot 51 \\
2 \cdot 06 \\
1.98 \\
1.90 \\
1 \cdot 84 \\
2 \cdot 13 \\
2 \cdot 41 \\
2 \cdot 57 \\
2 \cdot 86\end{array}$ & $\begin{array}{l}4 \cdot 53 \\
4 \cdot 47 \\
4 \cdot 77 \\
4 \cdot 81 \\
4 \cdot 26 \\
4 \cdot 22 \\
5 \cdot 01 \\
4 \cdot 51 \\
4 \cdot 75 \\
5 \cdot 03 \\
4 \cdot 90 \\
4 \cdot 48\end{array}$ & $\begin{array}{l}4 \cdot 53 \\
4 \cdot 56 \\
4 \cdot 86 \\
4 \cdot 75 \\
4 \cdot 56 \\
4 \cdot 23 \\
5 \cdot 05 \\
4 \cdot 50 \\
4 \cdot 57 \\
5 \cdot 13 \\
4 \cdot 76 \\
4 \cdot 48\end{array}$ & $\begin{array}{l}4 \cdot 31 \\
4 \cdot 50 \\
4 \cdot 65 \\
4 \cdot 57 \\
4 \cdot 35 \\
4 \cdot 06 \\
4 \cdot 84 \\
4 \cdot 51 \\
4 \cdot 50 \\
5 \cdot 03 \\
4 \cdot 71 \\
4 \cdot 48\end{array}$ & $\begin{array}{l}\text { lbs. } \\
0.86 \\
1.90 \\
2.33 \\
2.22 \\
1.61 \\
1.44 \\
1.10 \\
0.49 \\
0.58 \\
0.82 \\
0.71 \\
0.78\end{array}$ & $\begin{array}{l}\text { lbs. } \\
0.85 \\
1.94 \\
2.44 \\
2.33 \\
1.93 \\
1.59 \\
1.28 \\
0.56 \\
0.63 \\
0.87 \\
0.70 \\
0.77\end{array}$ & $\begin{array}{l}\text { lbs. } \\
0 \cdot 75 \\
1 \cdot 78 \\
2 \cdot 23 \\
2 \cdot 16 \\
1 \cdot 80 \\
1 \cdot 45 \\
1 \cdot 16 \\
0.52 \\
0 \cdot 57 \\
0 \cdot 83 \\
0.66 \\
0.73\end{array}$ & $\begin{array}{c}\text { lbs. } \\
+0.03 \\
-0.10 \\
-0.55 \\
-0.33 \\
+0.13 \\
+0.09 \\
+0.41 \\
+0.50 \\
+0.32 \\
-0.11 \\
-0.11 \\
+0.03\end{array}$ & $\begin{array}{c}\text { los. } \\
+0.04 \\
-0.14 \\
-0.66 \\
-0.44 \\
-0.19 \\
-0.06 \\
+0.23 \\
+0.43 \\
+0.27 \\
-0.16 \\
-0.10 \\
+0.04\end{array}$ & $\begin{array}{c}\text { lbs. } \\
+0.14 \\
+0.02 \\
-0.45 \\
-0.27 \\
-0.06 \\
+0.08 \\
+0.35 \\
+0.47 \\
+0.33 \\
-0.12 \\
-0.06 \\
+0.08\end{array}$ \\
\hline $\begin{array}{l}\text { Sept._Dec. } \\
\text { Jan._April } \\
\text { May-A ug. }\end{array}$ & $\begin{array}{r}10 \cdot 90 \\
7 \cdot 78 \\
9 \cdot 47\end{array}$ & $\begin{array}{l}4 \cdot 67 \\
4 \cdot 43 \\
4 \cdot 78\end{array}$ & $\begin{array}{l}4 \cdot 71 \\
4 \cdot 56 \\
4 \cdot 74\end{array}$ & $\begin{array}{l}4 \cdot 54 \\
4 \cdot 38 \\
4 \cdot 69\end{array}$ & $\begin{array}{l}7 \cdot 31 \\
4 \cdot 64 \\
2 \cdot 89\end{array}$ & $\begin{array}{l}7 \cdot 56 \\
5 \cdot 36 \\
2 \cdot 97\end{array}$ & $\begin{array}{l}6.92 \\
4.93 \\
2 \cdot 79\end{array}$ & $\begin{array}{l}-0.95 \\
+1 \cdot 13 \\
+0 \cdot 13\end{array}$ & $\begin{array}{l}-1.20 \\
+0.41 \\
+0.05\end{array}$ & $\begin{array}{l}-0.56 \\
+0.84 \\
+0.23\end{array}$ \\
\hline $\begin{array}{l}\text { Oct.-Mar. } \\
\text { April-Sept. }\end{array}$ & $\begin{array}{l}14 \cdot 49 \\
14 \cdot 16\end{array}$ & $\begin{array}{l}4 \cdot 58 \\
4 \cdot 70\end{array}$ & $\begin{array}{l}4 \cdot 66 \\
4 \cdot 67\end{array}$ & $\begin{array}{l}4 \cdot 48 \\
4 \cdot 59\end{array}$ & $\begin{array}{r}10 \cdot 60 \\
4 \cdot 24\end{array}$ & $\begin{array}{r}11 \cdot 51 \\
4 \cdot 38\end{array}$ & $\begin{array}{r}10.58 \\
4.06\end{array}$ & $\begin{array}{l}-0.35 \\
+0.66\end{array}$ & $\begin{array}{l}-1 \cdot 26 \\
+0.52\end{array}$ & $\begin{array}{l}-0.33 \\
+0.84\end{array}$ \\
\hline Year....... & $28 \cdot 65$ & $4 \cdot 61$ & $4 \cdot 66$ & $4 \cdot 51$ & $14 \cdot 84$ & $15 \cdot 89$ & $14 \cdot 64$ & +0.31 & -0.74 & +0.51 \\
\hline
\end{tabular}

the drainage from the three gauges contain respectively $5 \cdot 03,5 \cdot 13$, and 5.03 per million of chlorine, and in February when the minimum amounts of $4.22,4.23$, and 4.06 per million are reachel. Comparing the summer and winter drainage the amounts of chlorine are practically identical in the case of the 40-inch gauge and differ only by 0.1 per million in the 20- and 60-iuch gauges, the higher numbers occurring in the summer drainage. Under the circumstances it is obvious that the amounts of chlorine per acre vary directly in relation to the amount of the drainage. 
Comparing the average monthly amounts per acre of chlorine in the drainage with the average quantity found during the same period of 28 years in the rain it is seen that, speaking generally, the soils of the gauges lose chlorine in the winter months and gain in the summer months. In each case there is a loss from October to December, and a gain from February to May, the greater portion of the excess occurring in March, April, and May. The greatest loss is in November, when the chlorine (per acre) in the rain is bighest, and the greatest gain in April (Fig. 4).

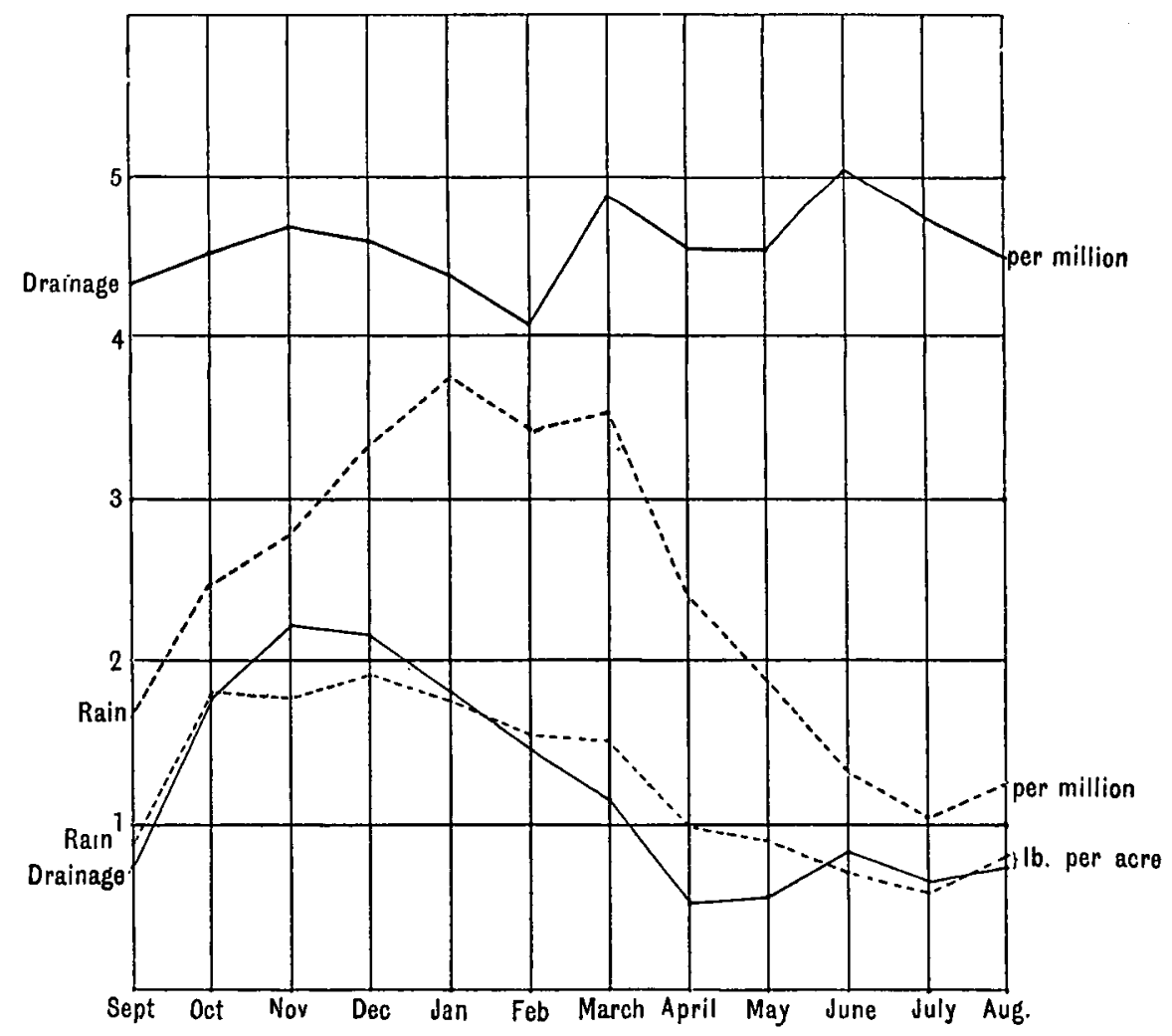

Fra. 4. Chlorine in rain and drainage through 60 inches of soil, per million and lbs. per acre. Average 28 years.

The yearly amounts of chlorine in the drainage (Table XII) are subject to great variations according to the amounts of drainage in the respective years and in that of the preceding years. In years of drought the soil may acquire several pounds of chlorine per acre from the rain (for instance, 1879-80, 1886-7, and 1897-8), whilst in wet years (1877-8, 1878-9, and 1902-3) there may be more or less considerable losses. 
Calculating the total gain or loss for the whole of 28 years the following numbers are obtained:

\begin{tabular}{|c|c|c|}
\hline \multirow{2}{*}{\multicolumn{2}{|c|}{20 inches of soil......... }} & Chlorine \\
\hline & & $\begin{array}{c}\text { lbs. per acre } \\
+\quad 8.68\end{array}$ \\
\hline 40 & & $-20 \cdot 72$ \\
\hline & $n \quad \ldots \ldots . . . .$. & +14.28 \\
\hline
\end{tabular}

From results of determinations of chlorine in samples of soil collected in 1870 near the gauges it is estimated that the soil of the 20-, 40-, and 60 -inch gauges originally contained 121,238 , and $342 \mathrm{lbs}$. of chlorine per acre respectively. These amounts seem to have been washed out of the soil during the first few years of the experiments. Frankland (6) found in samples of the drainage collected in November and December, 1870 , after heavy rainfall in October, amounts of chlorine varying from 21.5 to 38.0 per million. Since 1877 the highest result obtained in the monthly drainage of the 20 -inch gauge (which varies the most) has been 10.0 per million.

\section{REFERENCES.}

1. Greaves, C. On Evaporation and Percolation. Proc. Inst. C. E. 1875-6, 45, No. 1409.

2. Evans, J. On the Percolation of the Rainfall on Absorbent Soils. Ibid. No. 1478.

3. Lawes, J. B., Gilbert, J. H., and Warington, R. On the Amount and Composition of the Rain and Drainage Waters at Rothamsted. Part II. Journ. Roy. Agric. Soc. Eng. 1881, 42, 269, and 311. Rothamsted Memoirs, 5, No. 18.

4. Lawes, J. B., and GruBERT, J. H. Effects of the Drought of 1870 on some of the Experimental Crops at Rothamsted. Ibid. 1871, 32, 91. . Rothamsted Memoirs, 3, No. 11.

5. Gilbert, J. H. Observations on Rainfall, Percolation, and Evaporation. Proc. Inst. C. E. 1890-1, 105. Rothamsted Memoirs, 7, No. 2.

6. Frankland, E. Sixth Report of the Rivers' Pollution Commission, London, 1874.

7. Scotr, R. H. Results of Percolation Experiments at Rothamsted, Sept. 1870Aug. 1899. Quart. Jour. Roy. Met. Soc. 1900, 26, 139.

8. MiLL, H. R. British Rainfall, 1904. London, 1905.

9. KING, F. H. Iuvestigations in Soil Management. U. S. Dept. Agric. Bureau of Soils, Bul. No. 26, 1905.

10. Wollnx, E. Untersuchungen über den Einfluss der Mächtigkeit des Bodens auf die Feuchtigkeitsverhältnisse. Bied. Centr. 1894, 23, 146; from Wollny's Forschungen, 16, 1-14. 